\title{
Feeding Habits of Capybaras (Hydrochoerus hydrochaeris, Linnaeus 1766), in the Ecological Reserve of Taim (ESEC - Taim) - South of Brazil
}

\author{
Lucélia do Valle Borges and Ioni Gonçalves Colares* \\ Fundação Universidade Federal do Rio Grande; Departamento de Ciências Morfo-Biológicas; Av. Itália km 8; \\ Campus Carreiros; dmbioni@furg.br; 96201-900; Rio Grande - RS - Brasil
}

\begin{abstract}
The aim of this study was to determine feeding habitats of capybaras in the ESEC-Taim (RS, Brazil), using microhistological analyses of feces. Data were analyzed seasonally. In 172 samples analyzed, 17 species were identified, with predominance of Poaceae. Zizaniopsis bonariensis was the most frequent species in winter (38\%), spring (32\%) and summer (26.5\%) and Paspalum disthichum in fall (31.5\%). A observed increase in vegetation consumption during summer might be due to the food quality. Capybaras showed an opportunistic behavior in the winter and summer and a more selective behavior in spring and fall. Capybaras from the ESEC-Taim varied diet according to the season and alimentary availability.
\end{abstract}

Key words: Capybara, rodent, herbivory, diet, Poaceae

\section{INTRODUCTION}

The wild herbivores have developed different strategies of selection of the diet, according to the quality and abundance of victuals, the habitat type, the morphology and physiology of the animal (Galende and Grigera 1998). These animals possess strategies that allow the best nutritional use. On the other hand, the plants present defense mechanisms, such as polymeric complex as silica and lignin that reduce the digestibility (Shepherd and Cohen, 1997); tannins, or toxins that repel, or kill (Bozinovic et al., 1997), besides protection structures as the thorns, or trichomes (Howe and Westley, 1988). The content of fibers and the presence of secondary metabolites can influence in the foraging behavior and digestive efficiency of the herbivores (Bozinovic et al., 1997).
Studies on alimentary habit of wild species can be developed with direct observation of the animals in the field (Barreto and Herrera, 1998), but in many cases, this is very difficult and observation may be inaccurate; with analysis of the composition of the diet in samples of stomachal content, in that case with the sacrifice of the animal. This can be inadvisable when the species in subject are wild animals or when they are in extinction (Quintana et al., 1994). Other alternative is the non-invasive fecal analyses through technical microhistological (Abbas, 1991). The main advantages of the use of feces in these types of studies are: not to interfere with the habits of the animal, limitless number of samples, and eventually, the choice of comparing diets of two or more species of animals at the same time (Quintana et al., 1994).

\footnotetext{
* Author for correspondence
} 
The study of alimentary habits using microhistological analyses of feces was developed with squirrels originally by Baumgartner and Martin (1939). This technique has been used in different species of herbivores such as capybara (Hydrochaeris hydrochaeris) (Quintana et al., 1994), chinchilla (Lagidium viscacia) (Galende and Grigera, 1998; Galende et al. 1998), vizcacha (Lagostomus maximus) (Navarro et al., 1997; Kufner and Monk, 1998), nutria (Myocastor coypus) (Borgnia et al., 2000), guanacos (Lama guanicoe) (Puig et al., 2001) and Amazon manatee (Trichechus inunguis) (Colares and Colares, 2002).

The capybara (Hydrochoerus hydrochaeris Linnaeus 1766) is a wild herbivore, considered the largest rodent. The adults consume approximately $3 \mathrm{Kg} /$ day of fresh forage. The capybaras are selective grazers and choose plants with high protein content (González-Jiménez, 1978). Being a rodent, the digestive system of the capybara is similar to the rabbit, a Lagomorpha. The stomach is simple and the cecum is very voluminous. The chewed victuals are exposed to the action of symbiont microorganisms that inhabit the cecum of the animal to accomplish the fermentation, and they play an important part in the digestion (Mendes, 1986). The capybaras excrete two types of feces, an oval one in form of individual balls of green olive color and another of pasty consistency and clear coloration. The latter one, called cecotrofe, contains $37 \%$ more protein than the oval feces and they are ingested again, constituting an alimentary strategy (Mendes et al., 2000). Other alimentary strategy, observed by Lord (1994), is to regurgitate and to chew the food in the rest period. This study aimed to verify the frequency of occurrence of the vegetation in the feces of the capybaras of the Ecological Reserve of Taim (ESEC Taim), based on microhistological analysis.

\section{MATERIALS AND METHODS}

\section{Study area}

The wetlands of Taim, located in the Southern Coastal Plain, in a narrow strip between the Atlantic Ocean and the Mirim Lagoon, shelters most of the units of conservation in southern of Brazil, the Ecological Reserve of Taim (ESEC Taim). Located at the south of Brazil, in Rio Grande do Sul, among the $32^{\circ} 32^{\prime}$ and $32^{\circ} 50^{\prime}$ latitude $\mathrm{S}$ and $52^{\circ} 23^{\prime}$ and $52^{\circ} 32^{\prime}$ longitude W. It is on an area of 33,935 hectares with several ecosystems of several characteristics, as forests, fields, dunes, beaches, lakes and wetlands (Nogueira-Neto, 1993). ESEC Taim is inserted in the largest complex lake of South America, constituted by the Patos Lagoon, Mirim Lagoon, Mangueira Lagoon and several smaller lakes. The climate is seasonal, with cold and rainy winter and hot dry summer. The annual average precipitation is around $1,100 \mathrm{~mm}$ and the average temperature is $18^{\circ} \mathrm{C}$ (Paixão, 1984).

\section{Vegetation collection and capybara's feces}

The collection of herbaceous vegetation in flowering and recent feces of capybaras was accomplished monthly in one year. The collected plants were deposited in the Herbarium of the University of Rio Grande (HURG) and listed in Colares et al., 2001. A total of 133 species of herbaceous vegetation were collected, identified and distributed in 95genera and 41 families. Among these, 92 were dicotyledons, 39 monocotyledons and two pteridophytes (Colares et al., 2001). Parts of the plants were conserved in $70 \%$ alcohol and used in the assembly of the reference collection. Samples of fresh feces of adult capybaras were conserved in FAA $(85 \%$ ethyl alcohol, $10 \%$ formalin at 10\%, 5\% glacial acetic acid) for subsequent fecal analysis.

\section{Fecal analysis}

The fecal analysis consisted of the comparison between the fragments of epidermis of vegetable found in the feces of the animals, with epidermal layers of previously identified plants which mounted as a photomicrographic reference collection (Storr, 1961). For each sample conserved in FAA, three sub - samples and five microscope slides were prepared and analyzed, according to the method of Heinsohn and Birch (1972), modified by Colares and Colares (2002). These slides were analyzed in all their extension, being written down the type of material found. For identification, anatomical characteristics of the species were observed: size, shape and types of stomata, distribution, types and size of trichomes and presence of solid inclusions.

\section{Data treatment}

Data were contained to verify the vegetation consumed by the capybaras in ESEC Taim's area, considering seasonal variations. The frequency of 
each alimentary item was calculated every month of the year, according to the formula: $\mathrm{A} \%=$ (number of fragments of the item $\mathrm{i} /$ number of observed fragments) x 100, (Abbas, 1991).

\section{RESULTS}

Among the 133 species of the herbaceous vegetation collected, $14.8 \%$ was found in the diet of ESEC Taim's capybaras. A larger number of species occurred in spring (54), followed by summer (38), fall (28) and winter (13).

In 172 samples of analyzed feces, 2,681 showed the occurrences of fragments of epidermis of plants. The diversity of plants/samples of feces varied from 3 (May) to 12 (January). During the spring and fall a maximum of 8 and 9 species were observed for sample, while in winter and in summer, the number of species increased (10 and
14, respectively). There were 17 species identified, belonging to seven families with different habits (Table 1), and a total of $87 \%$ were classified as aquatic plants.

The Poaceae family was the most common, being found in 52.9\% of the samples analyzed. Table 2 shows the percent frequency of each food item for each season. Zizaniopsis bonariensis were the most frequent species in winter, spring and summer and Paspalum disthichum in fall.

The diet diversity was calculated with the Shannon index (Schafer, 1980) for each season, the values obtained for the diet were larger in summer $(\mathrm{H}=2.3)$ and winter $(\mathrm{H}=2)$, while it was similar in fall $(\mathrm{H}=1.8)$ and spring $(\mathrm{H}=1.9)$ (Table 2). The Hutchinson's test (Zar, 1984) showed significant difference $(p<0.05)$ between summer diet and other seasons (Table 3).

Table 1 - Species of plants identified in the capybaras feces (Hydrochoerus hydrochaeris Linnaeus 1766) in the Ecological Reserve of Taim (ESEC Taim). $\mathrm{A}=$ amphibious, $\mathrm{E}=$ emergent, $\mathrm{FF}=$ floating fasten, $\mathrm{FL}=$ floating free, $\mathrm{S}=$ submersed and $\mathrm{T}=$ terrestrial

\begin{tabular}{|c|c|c|c|}
\hline Family & Specie & Plant habits & $\begin{array}{c}\% \text { of } \\
\text { occurrences }\end{array}$ \\
\hline \multirow[t]{2}{*}{ Asteraceae (Compositae) } & Ambrosia tenuifolia Sprengel & $\mathrm{T}$ & 0.04 \\
\hline & Eclipta prostrata (L.) Linné & $\mathrm{A} / \mathrm{E}$ & 3.7 \\
\hline \multirow[t]{2}{*}{ Cyperaceae } & Cyperus ferax L. C. Rich. & $\mathrm{A} / \mathrm{E}$ & 0.1 \\
\hline & Cyperus polystachyos Rottb. & $\mathrm{T}$ & 0.04 \\
\hline Lamiaceae (Labiatae) & Stachys petiolosa Briq. & $\mathrm{T}$ & 0.2 \\
\hline Oenotheraceae & Epilobium angustifolium $\mathrm{L}$. & $\mathrm{T}$ & 9.4 \\
\hline \multirow[t]{9}{*}{ Poaceae (Gramineae) } & Cynodon dactylon (L.) Persoon & $\mathrm{T}$ & 1.0 \\
\hline & Echinochloa polystachya Hitchc. & $\mathrm{A} / \mathrm{E}$ & 7.7 \\
\hline & Panicum elephantipes Nees & $\mathrm{A} / \mathrm{E} / \mathrm{FF}$ & 1.3 \\
\hline & Paspalidium paludivagum (Hitchok et Chase) & $\mathrm{A} / \mathrm{FF} / \mathrm{S}$ & 12.9 \\
\hline & Paspalum disthichum $\mathrm{L}$. & A & 25 \\
\hline & Poaceae sp. & - & 2.1 \\
\hline & Polypogon chilensis (Kunth) Pilger & $\mathrm{T}$ & 0.1 \\
\hline & Setaria geniculata (Lam.) Beau. & $\mathrm{T}$ & 0.2 \\
\hline & Zizaniopsis bonariensis (Bal. Et poitr.) Spegazzini & $\mathrm{E}$ & 30.2 \\
\hline Polygonaceae & Polygonum punctatum Elliot & $\mathrm{A} / \mathrm{S}$ & 0.1 \\
\hline Pontederiaceae & Eichhornia crassipes (Mart.) Solms-Laubach & FL & 5.9 \\
\hline
\end{tabular}


Table 2 - Percentage of the vegetables found in the feces and seasonal diversity of the capybaras diet (Hydrochoerus hydrochaeris L. 1766) in the Ecological Reserve of Taim (ESEC Taim). H' = Index of diversity of Shannon.

\begin{tabular}{|c|c|c|c|c|}
\hline Specie & Summer(\%) & Fall(\%) & Winter(\%) & Spring(\%) \\
\hline A.tenuifolia & - & - & 0.3 & - \\
\hline E. prostrata & 13 & 0.3 & - & 1.5 \\
\hline C. ferax & 0.5 & - & - & - \\
\hline C. polystachyos & - & - & 0.3 & - \\
\hline S. petiolosa & - & - & - & 0.5 \\
\hline E. angustifolium & 19.4 & 5.8 & 5.2 & 6.8 \\
\hline C.dactylon & 2 & - & 4.9 & - \\
\hline E. polystachya & 5.7 & 5.6 & 1.6 & 12 \\
\hline P.elephantipes & 2.9 & 2.2 & 3.2 & - \\
\hline P. paludivagum & 11 & 12.4 & 20.8 & 11.7 \\
\hline P. disthichum & 13.9 & 31.5 & 19.5 & 28.7 \\
\hline Poaceae sp. & 0.8 & 6.3 & - & - \\
\hline P. chilensis & 0.6 & - & - & - \\
\hline S.geniculata & 1 & - & - & - \\
\hline Z. bonariensis & 26.5 & 26.8 & 38 & 32.1 \\
\hline P.punctatum & 0.5 & - & - & - \\
\hline E. crassipes & 2.2 & 9.2 & 6.2 & 6.7 \\
\hline $\mathbf{H}^{\prime}$ & 2.3 & 1.9 & 2 & 1.9 \\
\hline
\end{tabular}

Table 3 - Values of the test of Hutchinson, at 5\% of significance, among the indexes of seasonal diversity of the capybaras diet (Hydrochoerus hydrochaeris L. 1766) in the Ecological Reserve of Taim (ESEC Taim). $t=$ test $t$. GL $=$ degrees of freedom.

\begin{tabular}{lccccc}
\hline \multicolumn{1}{c}{ Comparison } & t & GL & t' & p & Result \\
\hline Summer - Fall & 4.6 & 388 & 1.967 & $<0.05$ & Different Diversity \\
Summer - Winter & 2.4 & 266 & 1.969 & $<0.05$ & Different Diversity \\
Summer - Spring & 4.7 & 362 & 1.967 & $<0.05$ & Different Diversity \\
Fall - Winter & 1.2 & 223 & 1.972 & $>0.05$ & Similar Diversity \\
Fall - Spring & 0.2 & 564 & 1.965 & $>0.05$ & Similar Diversity \\
Winter - Spring & 1.1 & 202 & 1.972 & $>0.05$ & Similar Diversity \\
\hline
\end{tabular}

\section{DISCUSSION}

In spite of the large number of herbaceous species found in ESEC Taim, just $14.8 \%$ of the total were present in the diet of the capybaras. These results suggested that there was a larger offer of herbaceous vegetation in ESEC Taim, that the capybaras used. This could be due to factors as palatability, or energy tenor of these plants, which would release the individuals' search for a great diversity of victuals. Water is essential for capybaras for thermoregulation and protection (Alho, 1989), being impeded to move away the water courses in search for feeding once the larger the distance, the larger the risk of predation. Similar behavior was observed with capybaras and nutria in Argentina, where they restricted their diet to plants near the watercourses, as defense strategy against predation (Quintana et al., 1998; Borgnia et al., 2000). 
Although in ESEC Taim, a large number of dicotyledonous were found (Colares et al., 2001), the capybaras showed the preference for the monocotyledons, only increasing the dicotyledons consumption in the summer. This phenomenon was also observed with nutria in Argentina that consumed more monocotyledons. However it maintained a constant relation between the two orders along the year (Borgnia et al., 2000). This preference for monocotyledons could be associated to the largest presence of secondary metabolites, reducing their nutritional value (Howe and Westley, 1988). This way in summer, when little green vegetation were available, in spite of the largest number of secondary metabolites, dicotyledon species started to constitute an important alimentary item for ESEC Taim's capybaras. Similar situation was observed with herbivores rodent in Argentina, where the dicotyledons use was related to the occurrence of apparent species (Borruel et at., 1998).

The diversity of plants for sample varied from 3 to 12 , not being observed samples with an only species. Lord (1994) reported that the capybaras in Venezuela selected species to graze, only passing to the other when it was drained. Theoretically, the decrease in the nutritious value and digestibility of the plants reduced its selectivity and palatability of the herbivores, so that when they ingested less nutritious plants they could compensate eating a larger number of species (Bozinovic et al., 1997). Variations in the number of species for sample could represent a nutritional complement, or feeding in widespread feeding grounds made up of different plants species (Colares and Colares 2002). The variations observed in the diet of ESEC Taim's capybaras were probably related to an alimentary complementation given the diversification of species in the samples.

Species of Poaceae were more consumed by ESEC Taim's capybaras. Studies with capybaras in Venezuela (Barreto and Herrera, 1998) in Argentina (Quintana et al. 1998) and nutria in France (Abbas, 1991) also indicated species of Poaceae as the more consumed. During the growth, period with larger energy content, the leaves of Poaceae were consumed (Mcllroy, 1964). Species of this family generally answered the moderate pasture with growth of new nutritious sprouts. The regular maintenance of pasture areas guarantee high quality forage to the herbivores. The nutritional and the permanent viability of Poaceae were responsible for the preference of this resource for the nutria (Abbas, 1991) and probably, it also happened with ESEC Taim's capybaras.

Zizaniopsis bonariensis was the most frequent species in the capybaras feces, with $30.2 \%$ of the total of occurrences. This species had high occurrence frequency in all the seasons, mainly in the winter $(38 \%)$, when the offer of another alimentary items was smaller. The largest abundance of $Z$. bonariensis was probably, not only a preference of the capybaras due to its palatability, but also for the largest food offer. This species could be considered as the most abundant in the area due to great extension that occupied at ESEC Taim's wetland (personal observation). Colares and Colares (2002) observed similar with the Amazon manatee, where the most common vegetables in the Amazon Rivers were also more frequent in the diet of these animals. Diaz (2000) found a positive relationship among palatability of plants to rabbits and the abundance of the consumed species in terms of covering percentage.

Z. bonariensis was also mentioned as more consumed by the capybaras in the Low Delta of the river Paraná in Argentina due of its largest occurrence (Quintana et al. 1998). On the other hand, in studies of desolated areas of the river Paraná, Argentina, Carex riparia (Cyperaceae), typical of forestation areas, were mentioned as the most abundant in the diet of the capybaras due to the largest availability (Quintana et al., 1994), which demonstrated a behavior opportunist.

Paspalum disthichum was the second species more consumed along the year (25\%), being in the fall the more ingested item, with smaller ingestion in the summer when the flowering occurred. According to Abbas (1991), during the flowering of Poaceae, the digestibility and the level of proteins in the leaves decreased, while it increased the tannin content and fibers. This reduction in the protein value of the current leaves of the flowering period, as well as the fact of the foliage to come more drought, they were probably responsible for the decrease of consumption of all the Poaceae in the summer, especially of Paspalum disthichum.

The water hyacinth (Eichhornia crassipes) presented a percentage of occurrence of $5.9 \%$ (Table 1), with its consumption peak for ESEC Taim's capybaras in the fall (Table 2). Barreto and Herrera (1998) and Lord (1994), showed that capybaras cut off selectively the stem up to but rejecting the leaf. In this study, the analysis of 
feces didn't allow them to determinate the part consumed by the animal, due to likeness among the epidermis of these two organs.

According to some authors, in spite of the abundance in the habitat, aquatic plants did not constitute an important forage for the capybaras. In the Pantanal, Brazil, there were consumed moderately (Pott et al., 1986). In Venezuela, the frequency of occurrence of aquatic plants was $2 \%$ (Escobar and Gonzaléz-Jiménez, 1976) and in Argentina 0.6\% (Quintana et al., 1994; Quintana et al. 1998). However, in agreement with the definition of aquatic plants (Cook et al., 1974) and according to the classification in biological ways (Irgang and Gastal Jr., 1996), a larger number of species found in the capybaras feces were classified as aquatic plants (Table 1) in a total of $87 \%$. If this classification was to be considered, it was evident that ESEC Taim's capybaras had a diet essentially of aquatic plants, what was in agreement with the atmosphere where they lived, close to courses of water. In the summer, when the flooding level decreased (Colares et al., 2001), the percentage of ingested aquatic plants was smaller.

The values of the indexes of diversity of Shannon were larger in the summer and in the winter $(\mathrm{H}=2.3$ and $\mathrm{H}=2$, respectively). The test of Hutchinson showed that the diversity in the summer was significantly different $(\mathrm{p}<0.05)$ of the other seasons. Due to the temperate climate observed in ESEC Taim's area, with cold rainy winter and hot dry summer, two critical seasons appear, in terms of food offer to the capybaras. In the winter, when there is low food offer (Colares et al., 2001), the capybaras ingest the available items. In the summer, the quality of the forage drops due to drought, taking the capybaras to a diversification of the ingested items, seeking victuals that seem nutritious. In Argentina, according to Quintana et al. (1994; 1998), the only critical station is the winter, when the capybaras are more selective. In the rest of the year, the behavior is less selective, incorporating palatable alimentary items. In Venezuela, with tropical climate, where the critical time is the drought period, the alimentary behavior is more selective when the offer is abundant and less selective when the quality of the forage, or the offer, is low (Barreto and Herrera, 1998).

In the spring, the occurrence of species increased, as Paspalum disthichum and Echinochloa polystachya. The increase and the consumption of these Poaceae were probably related to the appearance of new sprouts and of tender more palatables leaves. Due to a larger readiness of victuals, the capybaras pass to a more selective behavior, similar to the one observed by Barreto and Herrera (1998) in Venezuela.

Plants, whose frequency of observed occurrence is very low $(<1 \%)$, could suffer accidental ingestion with the consumed species. In this case, a rejection to two Cyperaceae (0.04 and 0.1\%) was observed, different from the capybaras studied by Quintana et al. (1994) in Argentina, where the main alimentary item (Carex riparia) was Cyperaceae. In agreement with Arnold (1987), herbivore mammals presented forage strategies related with its metabolic rates, size and anatomy of the digestive treatment. Like this, if the capybaras possessed a high digestive efficiency as affirmed by González-Jiménez (1978), it was possible to suppose that the ingestion of few alimentary items along the year supplied its nutritional solicitations, without the need of a larger alimentary diversification. Moreover, capybaras were grazers selective, choosing plants with high protein level (Alho, 1986).

In conclusion, it was possible to say that ESEC Taim's capybaras varied their diet according to season and readiness of victuals, alternating the alimentary items to supply their nutritional needs. In the critical seasons, as winter and summer, when the quality, or offer decreased, they showed an opportunist behavior, passing to a more selective diet when the offer of victuals increased.

\section{ACKNOWLEDGMENTS}

The authors thank the Departamento de Ciências Morfo-Biológicas (DCMB) of the Fundação Universidade Federal do Rio Grande (FURG), for the readiness of the resources used in the execution of this work; the Fundação de Assistência a Pesquisa do Estado do Rio Grande do Sul (FAPERGS), for financing the project and concession of scholarship on scientific initiation; and to Dr. César Vieira Cordazzo, Dr. Elton Pinto Colares, Dr. Joaber Pereira Jr. and the anonymous reviewers for reading and giving suggestions in the manuscript. 


\section{RESUMO}

O principal objetivo deste estudo foi determinar os hábitos alimentares das capivaras na ESEC-Taim baseado na análise microhistologica de suas fezes. Os dados foram analisados sazonalmente. Em 172 amostras analisadas, foram identificadas 17 espécies, com predominância de Poaceae. Zizaniopsis bonariensis foi a espécie mais freqüente no inverno (38\%), primavera $(32 \%)$ e verão $(26,5 \%)$ e Paspalum disthichum no outono $(31,5 \%)$. O aumento no consumo da vegetação durante o verão pode ser explicado devido à qualidade da vegetação. As capivaras mostram um comportamento de oportunismo nas estações de inverno e verão e um comportamento mais seletivo na primavera e outono. Concluindo, as capivaras da ESEC-Taim variam sua dieta de acordo com a estação e a disponibilidade de comida.

\section{REFERENCES}

Abbas, A. (1991) Feeding strategy of coypu (Myocastor coypus) in Central Western France. J. Zool., Lond., 224: 385-401

Alho, C.J.R. (1986) Criação e manejo de capivaras em pequenas propriedades rurais. EMBRAPA-DDT, Brasília-DF.

Alho, C.J.R., Campos, V.M. and Gonçalves, H.C. (1989) Ecology, social behavior and management of the capybara (Hydrochaeris hydrochaeris) in the Pantanal of Brazil. In: Advances in Neotropical Mammalogy Redford, K.H. and Eisenberg, J.F. eds. Gainesville, The Sandhill Crane. pp. 163-194.

Arnold, G. (1987) Influence of the biomass, botanical composition and the sward heigh of annual pastures on foraging behaviour by sheep. J.Applied.Ecol., 24: 759-772.

Barreto, G.R. and Herrera E. A. (1998) Foraging patterns of capybaras in a seasonally flooded savanna of Venezuela. J. Tropical Ecology, v. 14, 87-98.

Baumgartner, L.L and Martin, A.C. (1939) Plant histology as an aid in squirrel food habits. J. Wildl. Manage., Vol.3, n. 3, 266-268.

Beçak, W. and Paulete-Vanrell, J. (1970) Técnicas de citologia e histologia. Livraria Nobel S.A.

Borgnia, M., Galante, M.L. and Cassini, M.H. (2000) Diet of the coypu (nutria, Myocastor coypus) in agrosystems of Argentinean pampas. J. of Wildl. Manage. Vol. 64, n.2: 354-361.
Borruel, N., Campos, C.M., Giannoni, S.M. and Borghi, C.E. (1998) Effect of herbivorous rodents (cavies and tuco-tucos) on a shrud community in the Monte Desert, Argentina. J. of Arid Environments. n. 39, 3337.

Bozinovic, F., Novoa, F.F., Sabat, P. (1997) Feeding and digesting fiber and tannins by an herbivorous Rodent, Octodon degus (Rodentia: caviomorpha). Comp. Biochem. Physiol. Vol. 118 ${ }^{\mathrm{A}}$, n. 3, 625-630.

Braga, M.M.N. (1982) Aspectos anatômicos das folhas de Virola aublet (Myristicaceae) como contribuição para sua taxonomia. Tese de Doutorado. INPA/FUA. Manaus, AM.

Colares, I.G., Perazzolo, M., Borges, L., Freire, M. and Neves, L.F. (2001) A vegetação herbácea da Estação Ecológica do Taim (ESEC Taim). In: Anais do $1^{\circ}$ Simpósio de áreas protegidas - Pesquisa e desenvolvimento sócio-econômico. Pelotas - RS/ Brasil, 185-190.

Colares, I.G. and Colares, E.P. (2002) Food plants eaten by Amazonian manatees (Trichechus inunguis, Mammalia: Sirenia). Brazilian Archieves of Biology and Technology. Vol. 45, n. 1: 67-72

Cook, C.D.K., Gut, B.J., Rix, E.M. Schneller, J. and Seitz, M. (1974) Water plants of the world. W. Junk Publ. The Hague. England.

Diaz, A. (2000) Can plant palatability trials be used to predict the effect of rabbit grazing on the flora of exarable land? Agriculture, Ecosystem and Environment, n. 78, 249-259.

Escobar, A. and González-Jiménez, E. (1976) Estudio de la competencia alimenticia de los herbívoros mayores del Lhano inundable com especial al chiguire (Hydrochaeris hydrochaeris). Agronomia Tropical. v. 26, n. 3, 215-227.

Galende, G.I. and Grigera, D. (1998) Relaciones alimentárias de Lagidium viscacia (Rodentia, Chinchillidae) com herbívoros introducidos en el Parque Nacional Nahuel Huapi, Argentina. Iheringia, Sér. Zool., n. 84, 175-184.

Galende, G.I., Grigera, D. and von Thüngen, J. (1998) Composición de la dieta del chinchillón (Lagidium viscacia, Chinchillidae) en el noroeste de la Patagonia. Mastozoologia Neotropical, n. 5 (2), 123128.

González-Jiménez, E. (1978) Digestive physiology and feeding of capybara (Hydrochaeris hydrochaeris). In: Handbook series in nutrition and food. Ed. M.Recheigl. CRC Press, Cleveland. Sect.9,1: 163177.

Heinsohn, G.E. and Birch, W.R. (1972) Foods And feeding habits of the dugong, Dugong dugon (Erxeben) in Northern Queensland, Australia. Mammalia., v. 36, 414-422.

Howe, H.F. and Westley, L.C. (1988) Ecological relationships of plants and animals. Oxford University Press, New York. 
Irgang, B.E. and Gastal Jr., C.V.S. (1996) Macrófitas aquáticas da planície costeira do RS. Porto Alegre.

Kufner, M.B. and Monge, S. (1998) Dieta De Lagostomus maximus (Rodentia, Chinchillidae) en areas sometidas a intervención humana en el desierto del Monte, Argentina. Iheringia, Sér. Zool., n. 84, 175-184.

Lord, R.D. (1994) A descriptive account of capybara behaviour. Studies on Neotropical Fauna an Environment, Vol. 29, n. 1, 11-22.

McIlroy, R.J. (1964) An introduction to tropical grassland husbandry. Oxford University Press, London.

Mendes, B.V. (1986) Capivara - Hydrochoerus hydrochaeriss hydrochaeris (Linnaeus). In: Anais do V Congresso Florestal Brasileiro, Recife, 5-23.

Mendes, A., Nogueira, S.S.C, Lavorenti, A. and Nogueira-Filho, S.L.G. (2000) A Note on the cecotrophy behavior in capybara (Hydrochaeris hydrochaeris). Applied Animal Behaviour Science, n. 66, 161-167.

Navarro, J.L., Rosati, V.R. and Fraire, E.C. (1997) Incidencia de vizcachas (Lagostomus maximus) en un cultivo de soja. Mastozoologia Neotropical, n. 4 (2), 137-144.

Nogueira-Neto, P. (1993) Do Taim ao Chuí - da barra do Rio Grande as terras e águas do Arroio Chuí. Empresa das Artes, São Paulo.

Paixão, I.L.S.C. (1984) Estação Ecológica do Taim. SEMA, Brasília.

Pastor, J. and Cohen, Y. (1997) Herbivores, the functional diversity of plants species, and the cycling of nutrients in ecosystems. Theoretical Population Biology, n. 51, 165-179.
Pott, A., Campos, Z. and Alho, C. (1986) Plantas da dieta da capivara de Nhecolandia, Pantanal: observações iniciais. In: Resumos do Congresso Nacional de Botânica, 27, Ouro Preto, Brasil.

Puig, S., Videla, F., Cona, M.I. and Monge, S.A. (2001) Use of food availability by guanacos (Lama guanicoe) and livestock in Northern Patagonia (Mendoza, Argentina). J. of Arid Environments. n. 47, 291-308.

Quintana, R.D., Monge, S. and Malvarez, A.I. (1994) Feeding habits of capybara (Hydrochaeris hydrochaeris) in afforestation areas of the Lower Delta of the Parana River; Argentina. Mammalia, v. 58, n. 4, 569-580.

Quintana, R.D., Monge, S. and Malvarez, A.I. (1998) Feeding patterns of capybara Hydrochaeris hydrochaeris (Rodentia, Hydrochaeridae) and cattle in the non-insular area of the Lower Delta of the Parana River; Argentina. Mammalia, v. 62, n. 1, 37-52.

Schäfer, A. (1980) Critérios e métodos para a avaliação das águas superficiais - Análise de diversidade de Biocenoses. NIDECO, Série Taim. n. 3.

Storr, G.M. (1961) Microscopic analysis of faeces, a technique for ascertaining the diet of herbivorous mammals. Aust. J. Biol. Sci., vol. 14, n. 1, 157 - 166.

Zar, J.H. (1984) Biostatistical Analysis. $2^{a}$ ed. PrenticeHall, Inc. New Jersey.
Received: May 03, 2005; Revised: March 16, 2006; Accepted: March 14, 2007. 